Anetta Breczko

Uniwersytet w Białymstoku e-mail: breczko@uwb.edu.pl telefon: +48 857457189

DOI: $10.15290 / \mathrm{mhi} \cdot 2014.13 .02 .20$

\title{
O potrzebie redefinicji pojęć "małżeństwo" i "rodzina" we współczesnym pluralistycznym świecie. Rozważania w kontekście związków partnerskich
}

\begin{abstract}
SUMMARY
The need to redefine the concepts of marriage and family in modern pluralistic world. Reflections in the context of partnerships

The present paper shows the need to redefine notions such as "marriage" or "family". The traditional model - based on European cultural heritage, mainly under the influence of Christianity - is facing a crisis. This is due especially to deep transformations of civilization. The definition of marriage as the union of a man and a woman, which serves for natural procreation purpose, is also questioned by biotechnological development. Attitude towards sexuality becomes more and more permissive. Family and sexuality belong to the private sphere, getting out of state and social control. In a pluralistic and multicultural world, there is a tendency to expand and develop the legal framework for informal and homosexual relationships. The institution of marriage is gradually losing its heterosexual character and begins to include same-sex partners. Moreover, public debate on polygamous and multilateral relations has already initiated in several democratic countries.
\end{abstract}

Key words: motherhood, marriage, monogamy, polygamy, fatherhood, family, partner relationships

Słowa kluczowe: macierzyństwo, małżeństwo, monogamia, poligamia, ojcostwo, rodzina, związki partnerskie

\section{Wielokulturowość jako źródło nowego podejścia do instytucji małżeństwa i rodziny}

Kultura stanowi społeczną spuściznę ludzkości. Jest utożsamiana z zorganizowanym sposobem życia, opartym na wspólnym otoczeniu. Obejmuje ludzką działalność skutkującą tzw. dorobkiem kulturowym, na który składają się dobra, wartości i dziedzictwo kulturowe. 
W nowoczesnych społeczeństwach widoczna jest pluralizacja zarówno świata zewnętrznego wobec człowieka, jak i świata wewnętrznego, czyli jego świadomości i wiedzy. Pluralizm prowadzi zatem do zmian nie tylko w sferze realnej. Zmienia się wraz z nim także zakres doświadczeń jednostki ${ }^{1}$. Wzmożona dyfuzja kulturowa powoduje, że określone składniki różnych kultur przejmowane są przez inne kultury. Następuje recepcja cudzych wzorców kulturowych. Jednocześnie widoczny jest proces akulturacji, polegający na tym, że zasadniczo odmienne społeczeństwa wchodzą ze sobą w bliskie, nieraz konfliktowe relacje, które stają się źródłem np. wojen religijnych. Ponadto zauważalne jest zjawisko synkretyzmu kulturowego, objawiające się przekształcaniem $\mathrm{w}$ jednorodne całości elementów pochodzących z genetycznie i historycznie odległych od siebie kultur ${ }^{2}$.

Teza, że współczesny świat stał się "globalną wioską" - w której jest miejsce dla różnych kultur - wydaje się niepodważalna. Różnorodność współistniejących ze sobą kultur jest konsekwencją przemian cywilizacyjnych, związanych m.in. z postępem technologicznym. Człowiek współczesny to człowiek mobilny, przemieszczający się po świecie, poznający kultury inne niż ta, z której się wywodzi. Media, a w szczególności współczesne technologie informacyjne, umożliwiają mu „obecność” w różnych kulturach, nawet bez konieczności wychodzenia z domu.

Dominujące staje się przekonanie, że ogromna różnorodność kultur - reprezentujących niepowtarzalne wartości - stanowi wielkie, wspólne i komplementarne dobro całej ludzkości. W dobie multikulturalizmu etnocentryzm wiążący się z przekonaniem, że własna kultura jest lepsza i wyższa od kultur obcych, traktowany jest wręcz jako przejaw prymitywizmu kulturowego.

Zauważyć należy, że gdy różne światy stykają się ze sobą tworzy się sytuacja pełna konfliktów i napięć. W miejsce pewności i oczywistości pojawia się konieczność konfrontacji z wieloma różnymi, odmiennymi, konkurencyjnymi $\mathrm{w}$ stosunku do siebie systemami wartości. Zaoferowane przez współczesne demokracje poczucie wolności skutkuje wzrastającą niepewnością, cechującą współczesnych ludzi ${ }^{3}$. Fragmentaryzacja i ambiwalencja - jako procesy społeczne - znajdują swoje odzwierciedlenie $\mathrm{w}$ sferze moralności $\mathrm{i}^{4}$.

$\mathrm{W}$ warunkach pluralizmu to co jeszcze do niedawna $\mathrm{z}$ perspektywy systemów moralnych traktowane było jako „oczywiste" i „normalne”, dziś zostaje poddane $\mathrm{w}$ wątpliwość, zakwestionowane, a nawet odrzucone. Ostatecznym

1 M. Libiszowska-Żółtkowska, Sekularyzacja - wróg czy sprzymierzeniec Kościoła katolickiego w Polsce, [w:] Sekularyzacja jako wyzwanie dla religii i Kościoła. Mity i rzeczywistość, red. J. Baniak, Poznań 2006, s. 279.

2 R. Tokarczyk, Wspótczesne kultury prawne, Warszawa 2012, s. 49-51.

3 Z. Bauman, Zindywidualizowane społeczeństwo, Gdańsk 2008, s. 194.

4 J. Mariański, Kontrowersje wokót relacji religii i moralności. Tożsamość czy rozbieżność? Studium socjologiczne, Toruń 2014, s. 95. 
kryterium wyboru wartości i norm staje się autonomiczna jednostka, która uzyskała możliwość przekształcania swojej tożsamości moralnej według zindywidualizowanych kryteriów ${ }^{5}$. Wielokulturowość jest szczególnym przypadkiem procesów przekształcania i negocjowania tożsamości w świecie zachodnim. Nowoczesna jednostka żyje w "świecie wyborów”, absolutnie nieuchronnych w społecznościach odmiennych światopoglądowo. Wybory te dotyczą także wartości. Zanika stopniowo tradycyjny ład moralny obowiązujący wszystkich. W obliczu różnorodności wartości, norm, stylów życia itp. budowanie tożsamości moralnej staje się zadaniem niezmiernie trudnym ${ }^{6}$. We współczesnych społeczeństwach moralność traci więc swoją moc integrującą. Przestaje być bazą dla spójności społecznej. Brakuje już odgórnego - wiążącego ogólnie - punktu odniesienia. Świat wartości i norm jest wyraźnie „rozmyty” i „nieprzejrzysty”. Absolutna moralność miała najczęściej swoje zakotwiczenie w Bogu. Oparta była na zewnętrznych albo wewnętrznych wzmocnieniach. Proces odchodzenia od niej wiąże się z ukierunkowaniem na własną osobę, jej interes i dobro7. Poszukiwanie własnej wartości i godności staje się przewodnim motywem nowych kształtów moralności. Istotnym jej elementem jest odpowiedzialność nie przed Bogiem, nie przed innymi, ale przed samym sobą. Reakcją na nowoczesny pluralizm staje się relatywizm ${ }^{8}$.

Cała kultura zachodnia nabiera cech indywidualistycznych. Sprzyja jednostkowej niezależności i wolności. Nastawienie do seksualności staje się coraz bardziej permisywne9. Rodzina i seksualność przechodzą do sfery prywatnej. Widoczny jest proces uwalniania się tych obszarów życia spod kontroli społecznej. Zasada pluralizmu pociąga za sobą zasadę neutralności światopoglądowej państwa, wedle której przekonania moralne nie mogą wpływać na rozwiązania prawne ${ }^{10}$.

Socjologowie współczesną epokę opisują często jako czas „słabych więzi”. Wskazują, że przelotne stosunki są dziś bardziej korzystne niż długotrwałe związki. Aktualna wersja nowoczesności jest „rozmyta”, „ciekła”, „rozproszona”, „amorficzna” i „zderegulowana"11. Niektórzy wieszczą wręcz koniec tradycyjnego małżeństwa. Podkreśla się, że w czasach „płynnej” nowoczesności kategoria ta straciła właściwie rację bytu. Niektórzy sarkastycznie zauważają, że np. w warunkach polskich małżeństwo to rzeczywiście trwały

\footnotetext{
5 Ibidem, s. 96.

6 Ibidem, s. 102.

7 Ibidem, s. 248.

8 P. L. Berger, Zasada wątpliwości. Poza relatywizmem i fundamentalizmem, „Dziennik” 2008, nr 93, dodatek „Europa”, s. 14-15.

9 A. Giddens, Socjologia, Warszawa 2012, s. 583-584.

10 M. Klinowski, Moralność, reprodukcja i homoseksualizm, „Diametros” 2005, nr 5, s. 21-50.

11 Z. Bauman, Płynna nowoczesność, Kraków 2006, s. 231.
} 
i nierozerwalny związek ludzi połączonych "na wieki” kredytem we frankach szwajcarskich.

Tempo życia, wydłużenie czasu jego trwania, rozluźnienie więzi międzyludzkich, różnorodność możliwości wyboru, konsumpcjonizm, czynniki ekonomiczne, desakralizacja itd. to czynniki, które powodują, że coraz bardziej atrakcyjne stają się tymczasowe kohabitacje. Liczy się możliwość zerwania związku w dowolnym momencie i z dowolnego powodu, w miarę jak zanikają pożądanie i potrzeba bliskości.

Z punktu widzenia współczesnych państw przynależnych do europejskiego kręgu kulturowego jeszcze do niedawna małżeństwo traktowane było jako sformalizowany związek kobiety i mężczyzny. Stanowiło fundament rodziny, obejmującej poza małżonkami także ich wspólne, małoletnie dzieci. Taki model wydawał się najbardziej wartościowy i pożądany. Miał swoje umocowanie $\mathrm{w}$ dominującej $\mathrm{w}$ europejskim kręgu kulturowym religii chrześcijańskiej. Dziś - w związku z wielokulturowością - zauważalna staje się potrzeba redefinicji pojęć "małżeństwo" i „rodzina”. Aktualne staje się pytanie, czy we współczesnych demokratycznych porządkach prawnych jest $\mathrm{w}$ ogóle miejsce na obowiązującą dotychczas zasadę monogamii. Pojawia się szereg wątpliwości dotyczących sposobu traktowania osób homoseksualnych żyjących w trwałych wspólnotach rodzinnych.

\section{Kilka uwag na temat tradycyjnej definicji małżeństwa i rodziny}

Jak wcześniej zostało już wspomniane, tradycyjne małżeństwo stanowi sformalizowany związek pomiędzy kobietą i mężczyzną, tworząc rdzeń rodziny wychowującej wspólne małoletnie dzieci. Odmienność płci małżonków jest zawarta jako nieodłączny element małżeństwa (rodziny), umożliwiający realizację podstawowej funkcji prokreacyjnej. Wiąże się ona m.in. z funkcją opieki nad wspólnym potomstwem i zabezpieczeniem relacji pomiędzy dzieckiem a rodzicami. Pierwotnie rodzina stanowiła najbardziej zwartą grupę społeczną. Była niezbędna $\mathrm{z}$ perspektywy funkcjonowania gatunku homo sapiens, chociażby „ze względu na długi okres niemowlęctwa oraz fakt, że matka małych dzieci nie może zebrać dostatecznych ilości pożywienia. U ludzi podobnie jak i u większości gatunków ptaków, bardzo ważnym członkiem rodziny stał się ojciec. Musiało to doprowadzić do podziału pracy. Mężczyźni wyprawiali się na polowania, a kobiety pozostawały $\mathrm{w}$ domu. Przejście od rodziny do małego plemienia było prawdopodobnie uwarunkowane tym, że w gromadzie skuteczniej się polowało"12. 
Głównym celem instytucji małżeństwa przez wieki było więc stworzenie warunków do przyjścia na świat i wychowywania dzieci: „Monogamiczne czy poligamiczne, stałe lub tymczasowe, małżeństwo zawsze odnosi się do tej relacji - co najmniej potencjalnej. Ustanawia prawne lub quasi-prawne więzi rodzicielstwa, wyznaczające podstawowe ludzkie doświadczenie pokoleniowości, i obowiązki oraz odpowiedzialność, które w naturalny sposób się z niego wywodzą"13. Tradycyjna rodzina to tzw. rodzina nuklearna. Składa się ona z pary małżeńskiej i dzieci ${ }^{14}$. Do niedawna - jak to zostało już wcześniej zasygnalizowane - uznawana była za podstawę stabilności i porządku społecznego ${ }^{15}$.

Przekonanie o „nienaruszalnej naturze” małżeństwa i rodziny nuklearnej mocno ugruntowało się w naszym kręgu kulturowym. Implikowane było wiarą religijną we wskazaną przez samego Boga "właściwą" postać małżeństwa (rodziny) i uznaniem, że wszystkie inne formy związków pomiędzy ludźmi są grzeszne i złe. Tego typu spojrzenie na małżeństwo jest jak najbardziej zasadne z perspektywy określonej religii. Można się jednak zastanawiać, czy powinno nadal determinować kształt świeckiego prawodawstwa regulującego koegzystencję ludzi o odmiennych przekonaniach religijnych i moralnych.

Od kilku dekad można obserwować zjawisko kryzysu tradycyjnego modelu rodziny nuklearnej. Kryzys ten jest konsekwencją przemian cywilizacyjnych. W wielu krajach od połowy XX wieku systematycznie słabnie stabilność związku małżeńskiego. Zauważyć można wzrost zainteresowania konkubinatem. Wiele ludzi, nawet wychowując dzieci, funkcjonuje, nie zawierając związku małżeńskiego. Spadkowi liczby małżeństw towarzyszy wzrost liczby rozwodów. Instytucja tradycyjnego małżeństwa i rodziny weszła w fazę schyłkową. Spoistość rodziny nuklearnej uległa osłabieniu pod niemal wszystkimi względami (łącznie z prokreacją) ${ }^{16}$. Na zmierzch pozycji i modelu tradycyjnej rodziny wpłynęło wiele czynników związanych z tzw. trzecią falą przemian cywilizacyjnych. Zdaniem A. Tofflera, jej ratowanie wymagałoby „zniszczenia komputerów, zablokowania rozwoju usług, środków masowego przekazu, wepchnięcia kobiet z powrotem do kuchni, zmniejszenia pensji młodych pracowników, tak aby jeszcze bardziej - i na dłużej - uzależnić ich od rodziny, zakazania antykoncepcji i obniżenia stopy życiowej całego społeczeństwa"17.

Zauważmy, że współczesne małżeństwa mają na celu nie tylko prokreację. To związki ludzi, którzy świadomie tworzą rodzinę sensu stricto, aby realizować także (a czasem nawet przede wszystkim) inne dążenia. Dzięki insty-

13 S. Shell, The Liberal Case Against Gay Marriage, „The Public Interest” 2004, nr 156, s. 7.

14 A. Toffler, Trzecia fala, Warszawa 1986, s. 260 i nast.

15 Zob. szerzej P. Fiedorczyk, Attempts at Redefining the Family in Contemporary Polish Law, "International Journal of the Jurisprudence of the Family" 2012, nr 3, s. 358.

16 F. Fukuyama, Wielki wstrząs. Natura ludzka a budowa porządku społecznego, Warszawa 2000, s. 42-51.

17 A. Toffler, op. cit., s. 260. 
tucjom małżeństwa i rodziny możliwa jest realizacja podstawowych pragnień i potrzeb ludzkich: miłości, przyjaźni, współdziałania, odpowiedzialności za siebie i najbliższą osobę itd. Małżeństwo i rodzina stają się częścią tożsamości człowieka. Stanowią fundament współegzystencji duchowej i materialnej ludzi, dając im poczucie bezpieczeństwa. Są rodzajem społecznego rytuału podlegającego ochronie prawnej. Umożliwiają jednostkom pełne uczestnictwo w człowieczeństwie. Można skonstatować, że pojęcia „małżeństwo" i „rodzina” mają obecnie jako nazwy instytucji prawnych takie znaczenie, jaką treść normatywną zawierają dotyczące ich regulacje prawne ${ }^{18}$.

\section{Zasada monogamii i zakaz bigamii rozpatrywane z perspektywy współczesnych uwarunkowań kulturowych}

We współczesnych mobilnych, pluralistycznych społeczeństwach, w których to dochodzi do nieuchronnego przenikania się kultur, widoczna stała się różnorodność ludzkich zwyczajów dotyczących małżeństwa. Wielokulturowość przyczyniła się niewątpliwie $\mathrm{w}$ największym stopniu do filozoficzno-prawnej dyskusji dotyczącej zasadności bardzo wąskiego ujmowania pojęć „rodzina” i „małżeństwo”. Coraz częściej traktuje się dziś związek małżeński w sposób rozszerzający, podkreślając, że małżeństwo jest - zawartą w obliczu społeczności lub jej reprezentanta - umową pomiędzy co najmniej dwiema osobami; swoistym kontraktem dotyczącym wspólnego życia, określającym wzajemne uprawnienia i obowiązki stron ${ }^{19}$. Podobne "rozszerzające" ujęcie zauważalne jest przy definiowaniu pojęcia „rodzina”.

Formy, jakie mogą przybierać związki małżeńskie i rodzinne, są - z perspektywy dziejów ludzkich - bardzo różnorodne. Tym samym upowszechniony w świadomości społecznej podział na małżeństwa monogamiczne i poligamiczne wydaje się mocno uproszczony. Związki małżeńskie zaczęły pojawiać się już około dziesięciu tysięcy lat temu. Od najdawniejszych czasów najpopularniejsza była tzw. monogamia otwarta (od gr. monos - jedno i gamos - małżeństwo). Monogamia taka dopuszczała pozamałżeńskie kontakty seksualne pod warunkiem nierozwiązywania istniejących już więzi małżeńskich. Obok niej funkcjonowała także poligynia (od gr. poli - wiele i gyne - kobieta lub żona) ${ }^{20}$ oraz poliandria (od gr. poli - wielu i andros - mężczyzn lub mężów). Ta ostatnia występowała bardzo rzadko, co przyczyniło się do traktowania jej jako anomalii. Różne były przyczyny pojawiania się

18 T. Pietrzykowski, Wyzwania moralne. Etyczne problemy prawa, Katowice 2010, s. 157. 
alternatywnych do monogamii rodzajów małżeństwa. Z perspektywy tworzenia się związków poligynicznych dominującą rolę odgrywały czynniki demograficzne (przewaga liczebna kobiet) oraz biologiczne (większy popęd seksualny mężczyzn). Często przyczyną ich powstawania była niepłodność kobiety, którą zastępowała $\mathrm{w}$ funkcjach reprodukcyjnych druga żona, najczęściej jej siostra. Taka forma małżeństwa przetrwała do dziś w niektórych krajach afrykańskich (np. Egipt). Poliandria była natomiast sposobem na uniknięcie nadmiernego przyrostu liczby ludzi lub po prostu na zaspokojenie przyjemności kobiet. Praktykuje się ją do dziś np. w Tybecie i Indiach. Obok małżeństw monogamicznych i poligamicznych osób heteroseksualnych w wielu epokach, społeczeństwach i kulturach (zwłaszcza tych, które pozostawały poza wpływem oddziaływania chrześcijaństwa) istniały mniej lub bardziej uznawane społecznie związki osób tej samej płci (np. w antycznej kulturze greckiej i rzymskiej, kulturach indiańskich, afrykańskich czy azjatyckich). Związki takie staną się zasadniczym przedmiotem rozważań w tym opracowaniu, gdyż zauważalny jest wzrastający permisywizm moralny i prawny, skutkujący tendencją do ich legalizacji we współczesnych demokratycznych państwach. W tym miejscu wspomnieć jeszcze należy o szczególnym rodzaju związków rodzinnych, znanym w wielu kulturach i funkcjonującym również obecnie. Chodzi o tzw. małżeństwa multilateralne (grupowe). W związkach takich przynajmniej cztery dorosłe osoby: heteroseksualne i biseksualne połączone są wzajemną poligynią lub/i poliandrią. Związki te mogą przybierać postać małżeństw parzystych lub nieparzystych (kiedy np. liczba żon przewyższa liczbę mężów lub odwrotnie). Małżeństwa multilateralne występują nadal wśród Indian Ameryki Południowej, ale także na północy Alaski (wśród Inuitów) czy w środkowej Australii (wśród Dierów i Urabunów) ${ }^{21}$.

Z perspektywy współczesnych państw demokratycznych związki monogamiczne są - co już zostało wspomniane - uznawane za najbardziej wartościowe. Powszechna akceptacja tej formy małżeństwa jest rezultatem postępu cywilizacyjnego i związanych z tym uwarunkowań społecznych, ekonomicznych oraz religijnych. Prawo w społeczeństwach demokratycznych wyrosło na tradycji judeochrześcijańskiej, która silnie promowała i nadal promuje tzw. monogamię zamkniętą (wyłączną), niedopuszczającą pozamałżeńskich związków seksualnych ${ }^{22}$. Różnorodne formy innych związków w społeczeństwach zachodnich pod wpływem chrześcijaństwa - zostały na wiele stuleci właściwie całkowicie wyeliminowane. Dotyczyło to również praktyk homoseksualnych.

\footnotetext{
21 A. Lewandowska, Nieprzeciętność a formy matżeństw i demokracja, [w:] Nieprzeciętność. Dylemat wolności, red. M. Szyszkowska, A. Rossmanith, Warszawa 2013, s. 163-171. 
Zauważyć należy, że wyjątkowość, niepowtarzalność każdego człowieka skutkuje różnorodnością potrzeb ludzkich. Konsekwencją różnorodności jest skłonność do życia według indywidualnych potrzeb. Wyrazem tego jest także życie w odmiennych strukturach małżeńskich. W pełni należy zgodzić się z opinią, że „Każda z zaprezentowanych form małżeństwa jest dobra, o ile wybierana jest dobrowolnie, istnieje możliwość wyjścia z takiego związku oraz odwołania się do prawa w przypadku bycia pokrzywdzonym" ${ }^{23}$. W społeczeństwie polskim, zdominowanym przez religię chrześcijańską, większość ludzi długo jeszcze będzie się decydować na tradycyjne małżeństwa monogamiczne. Chociaż poligamia wydaje się na razie w Polsce abstrakcją, to i u nas pojawi się wkrótce ten problem, zwłaszcza że dyskusja taka rozpoczęła się już na świecie, m.in. w Kanadzie, USA, a także w Szwecji. Coraz częściej uznaje się, że małżeństwo powinno być neutralne nie tylko co do płci, ale także liczby osób, które chciałyby związek tworzyć.

Debata dotycząca zasadności legalizacji poligamii w demokratycznych państwach rozpoczęła się kilka lat temu w Kanadzie. Walkę o prawo do posiadania wielu żon podjęli wtedy wyznawcy Kościoła Jezusa Chrystusa Świętych w Dniach Ostatnich, mormoni z miasteczka Bountiful przy granicy z USA. Podkreślali, że poligamia jest fundamentem ich religii, która zobowiązuje mężczyzn do posiadania minimum trzech żon. Inaczej po śmierci nie mają oni szans na to, by dostać się do raju. Mormoni uważali zgodnie, że zapisana w konstytucji Kanady wolność religijna daje im prawo do preferowanego przez nich modelu rodziny. W listopadzie 2014 roku kanadyjski minister emigracji, Chris Alexander, zaprezentował projekt zmian $\mathrm{w}$ prawie, które m.in. mają zakazać pobytu w kraju imigrantów praktykujących wielożeństwo. Kanada nie stała się więc na razie (wbrew prognozom mediów) pierwszym demokratycznym państwem, które $\mathrm{w}$ imię wolności wyznania zalegalizuje wielożeństwo. Wręcz przeciwnie, niektóre praktyki mniejszości religijnych uznano tam za przejaw barbarzyństwa.

Związki poligamiczne imigrantów stanowią poważny problem w Unii Europejskiej, która nie zezwala na wydawanie prawa pobytu na jej terytorium takim małżeństwom. Osoba pochodząca z kraju, gdzie wielożeństwo jest legalne, może - jeśli oczywiście dostanie prawo pobytu - sprowadzić tylko jednego małżonka. Kraj członkowski decyduje, czy przyznać prawo pobytu dzieciom $\mathrm{z}$ jednego związku, czy też ze wszystkich małżeństw (problem ten widoczny jest np. we Francji, gdzie mniejszość muzułmańska, która akceptuje poligamię liczy pięć milionów ludzi) ${ }^{24}$.

Konwencje praw człowieka, będące dziełem cywilizacji Zachodu, nie obejmują dowolności odnośnie do tworzenia form małżeńskich. Brak ochrony 
prawnej skazuje osoby żyjące $\mathrm{w}$ związkach niemonogamicznych na dyskryminację, brak opieki socjalnej, stygmatyzację oraz wykluczenie ze społeczeństwa ${ }^{25}$.

W związku z procesem globalizacji i masowego przemieszczania się ludzi po świecie, kwestia prawnego uznawania zawartego wcześniej małżeństwa poligamicznego jest kontrowersyjna $\mathrm{w}$ krajach dopuszczających zawieranie tylko małżeństw monogamicznych. Pojawia się pytanie: czy kraje europejskie powinny respektować małżeństwa np. muzułmanina z kilkoma kobietami? Z międzynarodowego prawa prywatnego wynika, iż należy uznawać ważnie zawarte małżeństwa $w$ innym państwie. Zgodnie jednak z klauzulą porządku publicznego małżeństwa poligamiczne można potraktować jako sprzeczne z zasadami krajowego porządku prawnego ${ }^{26}$.

Wiele racji można dopatrzyć się w poglądach W. Sadurskiego, który uważa, że zakaz bigamii wynikający z moralnej dezaprobaty dla małżeństw o charakterze niemonogamicznym sprzeczny jest $\mathrm{z}$ zasadą neutralności prawa. Wydaje się, iż wolność osobista to niepodważalna wartość, zaś jedyną racją dla wprowadzenia zakazów danego działania staje się „zasada krzywdy”. Należy zgodzić się z poglądem, że regulacja prawna nie może być motywowana wyłącznie określoną moralnością. Prawne konsekwencje bigamii można uznać za minimalne, gdyż prawo nie zakazuje faktycznego pożycia w większym gronie osób ${ }^{27}$.

\section{Tendencje legalizacji homoseksualnych związków partnerskich w demokratycznych państwach}

Pod koniec XX wieku postulat legalizacji związków (małżeństw) osób tej samej płci stał się przedmiotem intensywnej debaty publicznej w wielu demokratycznych państwach. Było to skutkiem nakładających się na siebie procesów społecznych, oddziałujących także na kształt porządków prawnych. Małżeństwo zaczęło być postrzegane jako instytucja o charakterze prywatnym. W coraz mniejszym stopniu stawało się sprawą legitymowanego zainteresowania społeczeństwa i państwa, natomiast $\mathrm{w}$ coraz większej mierze traktowane być zaczęło jako sprawa autonomicznych decyzji samych małżonków. Przejawem postępującego procesu „prywatyzacji” małżeństwa jest stopniowe znoszenie

25 D. Jabłoński, L. Ostasz, Zarys wiedzy o rodzinie, małżeństwie, kohabitacji i konkubinacie: perspektywa antropologii kulturowej i ogólnej, Olsztyn 2011, s. 237-238.

26 D. Bunikowski, Podstawowe kontrowersje dotyczace ingerencji prawa w sferę moralności, Toruń 2010, s. 368-369.

27 W. Sadurski, Neutralność moralna prawa. (Przyczynek do teorii prawa liberalnego), „Państwo i Prawo” 1990, z. 7, s. 40-41. 
barier dotyczących swobody wyboru małżonka oraz rozwiązania związku małżeńskiego (np. pojawienie się rozwodu „bez winy”). Równolegle następowało znoszenie rozmaitych form dyskryminacji grup mniejszościowych. Na gruncie prawa międzynarodowego publicznego i prawa wewnątrzpaństwowego tworzone były różnorodne ",antydyskryminacyjne” instrumenty prawne. Z czasem coraz powszechniejsze stało się przekonanie, że „rezerwowanie świętej pieczęci małżeństwa dla osób heteroseksualnych, gdy homoseksualistom są oferowane oddzielne, ale równe związki partnerskie, służy - i to służy wyłącznie - poniżeniu osób homoseksualnych poprzez wykluczenie ich z podstawowych instytucji społecznych"28. Uznano, że kryterium różnej płci partnerów jako legitymizujące do skorzystania z instytucji prawnej małżeństwa może być zasadnie odbierane jako przejaw praktyki dyskryminacyjnej.

Zauważalna stała się ewolucja postaw społecznych wobec samego homoseksualizmu. $\mathrm{W}$ konsekwencji tego procesu $\mathrm{w}$ wielu porządkach prawnych w XX wieku nastąpiła dekryminalizacja aktów homoseksualnych ${ }^{29}$. Jej symbolem stało się wykreślenie w 1992 roku homoseksualizmu z listy chorób Światowej Organizacji Zdrowia ${ }^{30}$.

W procesie legitymizującym związki homoseksualne niewątpliwy wpływ odegrało orzecznictwo sądów amerykańskich, dotyczące zakazu związków małżeńskich między osobami innych ras. Jeszcze na początku XX wieku małżeństwa takie były uznane za "nienaturalne" i "niemoralne”, a tym samym zakazane przez prawo. Sąd Najwyższy Stanów Zjednoczonych Ameryki Pó1nocnej uznał prawo do zakładania związku małżeńskiego za jedno z podstawowych praw osobistych o największym znaczeniu dla poszukiwania szczęścia przez wolnych ludzi. Stwierdził, że prawo do poślubienia lub niepoślubienia osoby innej rasy należy do jednostki i nie może być ograniczone przez prawodawcę ${ }^{31}$. Orzeczenie to otworzyło drogę do uznawania za dopuszczalne także związków osób tej samej płci.

Współczesne konstytucje państw demokratycznych zawierają obecnie zakazy dyskryminacji z jakiejkolwiek przyczyny, w tym również z powodu orientacji seksualnej. Z Traktatu Amsterdamskiego (1997) wynika, że Unia Europejska może podjąć stosowne działania zwalczające dyskryminację ze względu na płeć, rasę lub pochodzenie etniczne, religię lub wierzenia, niepełnosprawność, wiek lub orientację seksualną (art. 2 ust. 7). Państwo członkowskie naruszające zasadę niedyskryminacji seksualnej może być nawet zawieszone $\mathrm{w}$ prawach członka. Trybunał Praw Człowieka w Strasburgu wielokrotnie uznał, że od-

W. Eksridge, Equality Practice Civil Union and Future of Gay Rights, New York - London 2003, s. 156

Np. w Danii w 1933, na Węgrzech w 1962, w Anglii w 1967, w Niemczech w 1969, w Chinach w 1992, w Rosji w 1993 r.

30 T. Pietrzykowski, op. cit., s. 143-144.

31 Loving v. Wirginia (388 U.S. 1 z 1967 r.). 
powiedzialność karna za dobrowolne stosunki seksualne między osobami dorosłymi stanowi naruszenia prawa do prywatności i jest nieusprawiedliwioną ingerencją $w$ prawo do poszanowania życia rodzinnego ${ }^{32}$. Trybunał pozostawił państwom prawo do uznania granicy wieku, od którego stosunek homoseksualny jest legalny.

Za instytucjonalizacją związków osób tej samej płci przemawiają następujące argumenty: 1) wolności, 2) sprawiedliwości i 3) pewności obrotu prawnego.

Argument $\mathrm{z}$ wolności odwołuje się do zasady krzywdy J. S. Milla ${ }^{33}$. Przyjmuje się, że jeśli instytucjonalizacja związków partnerskich osób tej samej płci nie przyczynia się do krzywdy zainteresowanych, to powinna być prawnie dopuszczona na zasadach mniej lub bardziej zbliżonych do instytucji małżeństwa.

Argument ze sprawiedliwości nawiązuje do teorii sprawiedliwości J. Rawlsa ${ }^{34}$. Sprawiedliwe zasady funkcjonowania społeczeństwa ustala się zza tzw. zasłony niewiedzy, co ma zapewnić podjęcie decyzji w sposób bezstronny, wolny od formułowania ocen zgodnych z własnym, partykularnym interesem, wyznaczonym konkretną sytuacją, $\mathrm{w}$ jakiej znajduje się dana jednostka. Zdaniem Rawlsa podstawową zasadą, jaką za „zasłoną niewiedzy” musiałyby preferować racjonalne jednostki, jest przyznanie wszystkim obywatelom równego prawa do najszerszego zakresu równych podstawowych wolności, możliwych do pogodzenia z podobnym systemem wolności dla innych. „Reguły gry" są często niesprawiedliwe dla określonych członków społeczeństwa. Przyjęcie optyki Rawlsa wiąże się z odwróceniem perspektywy i skłania do namysłu, czy gdybyśmy od początku wiedzieli, że nasza orientacja będzie homoseksualna, sprzeciwialibyśmy się nadal idei związków osób tej samej płci.

Argument $\mathrm{z}$ pewności obrotu prawnego dotyczy najbardziej pragmatycznego aspektu zinstytucjonalizowanych związków osób tej samej płci. Wskazuje, że osoby homoseksualne spotykają się z licznymi utrudnieniami $\mathrm{w}$ obrocie prawnym.

Jako podstawowe racje przeciw instytucjonalizacji związków osób tej samej płci pojawiają się na ogół trzy argumenty: 1) z religii i moralności, 2) z demografii, 3) ze zmiany stosunków społecznych.

Argument $\mathrm{z}$ religii i moralności wiąże się z dogmatami leżącymi u podstawy wielu religii i dominującymi $\mathrm{w}$ kręgu kultury europejskiej systemami moralnymi. Wynika z nich, że orientacja homoseksualna lub praktykowany homoseksualizm są grzechem lub po prostu złem. Argumentu tego nie da się utrzymać w państwach demokratycznych, w których istnieje rozdział państwa od Kościoła. 
Argument z demografii opiera się na założeniu, że instytucjonalizacja związków osób tej samej płci przyczyni się do spadku urodzeń w społeczeństwie. Łatwo podważyć jego zasadność, zwłaszcza że współcześnie wiele dzieci rodzi się poza małżeństwem, zaś spadek urodzeń ma różne przyczyny.

Argument ze zmiany stosunków społecznych wiąże się z obawami, iż instytucjonalizacja związków osób tej samej płci doprowadzi do upadku moralnego społeczeństwa, hedonizmu społecznego oraz "przewartościowania” systemów wartości. Może skutkować „modą” homoseksualną i negacją małżeństw tradycyjnych ${ }^{35}$. Argumentacja taka jest również łatwa do obalenia, zwłaszcza z perspektywy badań statystycznych, które nie potwierdzają takiej tendencji.

Dotychczas $w$ stosunkowo niewielu państwach nastąpiła prawna redefinicja pojęć "małżeństwo" czy "rodzina”, skutkująca ochroną prawną związków osób homoseksualnych. W Europie stosowne regulacje prawne zostały wprowadzone w Holandii, Belgii, Szwecji, Norwegii i Hiszpanii. Różne formy instytucjonalizacji prawnej partnerstwa osób homoseksualnych obowiązują także na kontynencie północnoamerykańskim, $\mathrm{w}$ wybranych prowincjach i stanach kilku krajów południowoamerykańskich, w Australii i Nowej Zelandii oraz w $\mathrm{RPA}^{36}$.

Instytucjonalizację prawną związków homoseksualnych cechuje ogromna różnorodność. $Z$ perspektywy europejskiej przepisy dotyczące tego problemu różnią się zasadniczo zakresem wprowadzonych praw i obowiązków, sposobem regulacji, kwestią tworzenia nowej regulacji prawnej lub wpisywaniem nowych zasad $\mathrm{w}$ istniejący porządek prawny. Pomimo tego, zauważyć można cztery wiodące modele regulacyjne: 1) model małżeński, 2) model zarejestrowanego związku partnerskiego, 3) model umowy cywilnoprawnej i 4) model konkubencki (kohabitacyjny).

Najwięcej kontrowersji wzbudza model małżeński. Wiąże się on z faktycznym „otwarciem" instytucji małżeństwa dla pary osób niezależnie od płci partnerów. Ma swoje odzwierciedlenie w ustawodawstwie Holandii (ustawa o małżeństwach osób tej samej płci z 21 grudnia 2000 roku, ustawa o prawie do adopcji dziecka przez małżeństwa tej samej płci z 21 grudnia $2000 \mathrm{roku}$ ). Na gruncie prawa holenderskiego zrównane zostały właściwie małżeństwa różno- i jednopłciowe. Prawo to przewiduje jednak pewne wyjątki dla małżeństw homoseksualnych. W przypadku urodzenia dziecka przez jedną z kobiet, druga nie jest automatycznie uznawana za matkę dziecka; ponadto niedopuszczalna jest adopcja zagraniczna (tak jak w przypadku mał-

35 Przegląd argumentów „za” $\mathrm{i}$ „przeciw” instytucjonalizacji związków osób tej samej płci zob. D. Bunikowski, op. cit., s. 279-283.

36 P. Pilch, Modele regulacji prawnych dotyczacych związków partnerskich obowiq̨ujące w krajach europejskich - rys historyczny, s. 119, www.files.gildia.pl/reklama/abiekt/PPilch_ARTYKUL.pdf [15.12.2014]. 
żeństw heteroseksualnych). Podobne rozwiązania występują w Belgii, Hiszpanii i Norwegii ${ }^{37}$.

Model zarejestrowanego związku partnerskiego jest najstarszym i zarazem najpopularniejszym rozwiązaniem. Reguluje prawa i obowiązki partnerów podobnie do małżeństwa, nie zrównując jednak formalnie tych dwóch instytucji. Występuje w Danii (ustawa o zarejestrowanym partnerstwie z 7 czerwca 1989 roku). Obecny jest w pozostałych krajach skandynawskich: Norwegii, Szwecji, Islandii, Finlandii, ale także w Niemczech i Szwajcarii ${ }^{38}$.

Model umowy cywilnoprawnej zakłada, że państwo umożliwia dwóm osobom żyjącym wspólnie zawarcie swoistej umowy, której forma i postanowienia wynikają bezpośrednio z mocy ustawy ją ustanawiającej. Umowy takie podlegają rejestracji przez państwo, co nadaje im szczególny status. Partnerzy mają autonomię $\mathrm{w}$ tworzeniu ostatecznego kształtu treści umowy, która ma organizować ich wspólne życie. Są zobowiązani do wzajemnej pomocy materialnej. W zależności od regulacji danego państwa model ten dostępny jest dla par jednopłciowych lub także dla partnerów odmiennej płci. Przykładem państwa, w którym funkcjonuje on w "czystej formie” jest Francja (cywilny pakt solidarnościowy uchwalony ustawą z 13 października 1999 roku ${ }^{39}$.

Model konkubencki (kohabitacyjny) ogranicza ochronę państwa dwóch osób prowadzących wspólne życie. Ochrona taka dotyczy zazwyczaj wybranych kwestii majątkowych i prawa odmowy zeznań w postępowaniu karnym. W modelu tym nie istnieje zazwyczaj jednorodna regulacja, która określałaby zakres uprawnień przyznanych osobom „żyjącym wspólnie”. Można jednak uznać, że podstawowym elementem łączącym te regulacje jest brak jakiejkolwiek formalnej rejestracji związku. Przepisy ustaw często posługują się nieostrymi pojęciami typu: "osoba bliska”, "osoba pozostająca w faktycznym pożyciu", z reguły nie definiując płci takich podmiotów. Model ten ma swoje praktyczne odzwierciedlenie $\mathrm{w}$ krajach anglosaskich, głównie pozaeuropejskich, takich jak USA, Kanada, Australia i Nowa Zelandia. Przykładem państwa europejskiego, w którym funkcjonują najdalej idące rozwiązania prawne dotyczące osób żyjących w związkach nieformalnych jest Szwecja. Już w połowie lat osiemdziesiątych XX wieku uchwalono tam tzw. ustawę kohabitacyjną, obejmującą swym zakresem pary zarówno hetero-, jak i homoseksualne. Także Portugalia (2001) i Chorwacja (2003) wprowadziły do porządku prawnego ustawy uznające istnienie trwałych związków, bez względu na płeć partnerów, nadające takim związkom pewne uprawnienia $\mathrm{w}$ sferach związanych $\mathrm{z}$ niższym opodatkowaniem spadków, sprawami lokalowymi oraz nakładające na partnerów pewne obowiązki o charakterze finansowym. W niektórych krajach 
europejskich nadanie pewnych uprawnień partnerom tej samej płci nastąpiło w wyniku ingerencji sądów krajowych (np. Węgry) lub w wyniku orzeczenia Europejskiego Trybunału Praw Człowieka (np. Austria) ${ }^{40}$.

Reasumując rozważania na temat modeli normatywnych dotyczących związków partnerskich można stwierdzić, że występuje tendencja rozszerzania się regulacji prawnych dotyczących związków nieformalnych także na partnerów homoseksualnych. Instytucja małżeństwa straciła swój heteroseksualny charakter i obecnie obejmuje także partnerów jednopłciowych. Powyższa konstatacja wskazuje na potrzebę redefinicji pojęcia małżeństwa także $\mathrm{w}$ polskim prawie. W Polsce przejawem dezaprobaty dla innych niż tradycyjna forma małżeństw jest chociażby cyklicznie podpalana "tęcza" w Warszawie, symbol homoseksualizmu. Społeczeństwo polskie daje tym samym wyraz swojej niechęci do homoseksualnych związków partnerskich. Podkreślić należy, że próby ich legalizacji dokonywane były już w 2004 roku, kiedy to za sprawą ówczesnej senator, prof. M. Szyszkowskiej, do Sejmu trafił absolutnie nowatorski - z perspektywy polskiej - projekt ustawy o rejestrowanych związkach partnerskich. Wywołał on burzliwą debatę społeczną i ostatecznie okazał się zbyt kontrowersyjny z perspektywy dominującej w Polsce moralności chrześcijańskiej.

\section{Problemy związane $z$ definiowaniem rodzicielstwa (małżeństwa, rodziny) w kontekście postępu biotechnologicznego}

Postęp biotechnologiczny $\mathrm{w}$ dziedzinie medycyny podważa fundamenty tradycyjnej definicji małżeństwa i rodziny jako instytucji służących naturalnej prokreacji. Zauważyć należy, że nie wszystkie małżeństwa zawierane są obecnie $\mathrm{z}$ myślą o prokreacji i opiece nad potomstwem. Wiele par małżeńskich nie chce mieć dzieci. Inne $-\mathrm{z}$ rozmaitych powodów - pozbawione są szans na rodzicielstwo (np. wiek, problemy zdrowotne). Brak woli lub zdolności do posiadania potomstwa nie stanowi jednak prawnej przeszkody do zawarcia związku małżeńskiego. Co więcej, małżeństwa bezdzietne nie są w świetle prawa traktowane jako "gorsze" lub mniej „prawdziwe” od tych, które posiadają potomstwo. Współcześnie więc ani wola, ani zdolność do prokreacji oraz wychowania dzieci nie są uznawane za warunek zawarcia małżeństwa między osobami odmiennej płci ${ }^{41}$.

Wraz z pojawieniem się umów o macierzyństwo zastępcze pewnemu „rozchwianiu" uległy dotychczasowe paradygmaty prawne, związane $\mathrm{z}$ wizją rodziny. Pojawił się problem: która kobieta ma być matką prawną dziecka? Czy

41 T. Pietrzykowski, op. cit., s. 161. 
matka zastępcza, a zatem biologiczna (czyli kobieta, która dziecko urodziła), czy też może matka zamawiająca (ta, w której głowie zrodził się zamysł powołania do życia dziecka), a może jeszcze inna - matka genetyczna (dawczyni materiału genetycznego). Niepewność odnośnie do tego, kto jest matką implikuje wątpliwości dotyczące ojcostwa ${ }^{42}$. To oczywiście tylko wierzchołek góry problemów związanych z macierzyństwem zastępczym.

Zagrożenia związane $\mathrm{z}$ umowami surogackimi dobrze obrazuje orzecznictwo sądowe w tym zakresie. Najwięcej takich spraw rozpoznawały sądy amerykańskie. Dotyczyły one m.in. problemu komercjalizacji reprodukcji i eksploatacji kobiet ${ }^{43}$. Powyższa sytuacja sprowokowała do dyskusji na temat instrumentalizacji w traktowaniu ludzi: wykorzystywania kobiet jako „inkubatorów”, zaś dzieci jako przedmiotu umowy ${ }^{44}$. Sądy musiały wielokrotnie zmierzać się z problemem, która matka w wyniku zastosowania metody in vitro jest "bardziej" matką narodzonego dziecka. Czy w większym stopniu jest nią kobieta, która dziecko urodziła, czy też kobieta, która zamówiła usługę u surogatki dawczyni materiału genetycznego ${ }^{45}$. Pojawił się też problem tzw. dzieci niczyich, powstałych dzięki wykorzystaniu materiału genetycznego anonimowych dawców, których po urodzeniu nie chce żaden z potencjalnych rodziców; ani rodzice zamawiający usługę prokreacyjną, ani matka surogatka ${ }^{46}$.

Rozwój medycyny powoduje coraz to nowe dylematy związane z rodzicielstwem. Przeprowadzane są w praktyce kolejne eksperymenty, które prowadzą do jeszcze większego „rozchwiania” pojęć: „macierzyństwo” i „rodzicielstwo”. Przykładowo, w 2012 roku połączono komórki jajowe pochodzące od dwóch kobiet $\mathrm{w}$ jedną i $\mathrm{z}$ sukcesem ją zapłodniono. To pionierskie doświadczenie stworzono po to, by w przyszłości zapobiegać wrodzonym wadom genetycznym. W tej sytuacji dziecko nie powstałoby $\mathrm{w}$ wyniku połączenia komórki jajowej jednej kobiety i plemnika mężczyzny (tak jak w przypadku umów surogackich), ale w związku z udziałem jeszcze kolejnej osoby. Przypadek ten

42 M. Soniewicka, Prokreacja medycznie wspomagana, [w:] J. Stelamch, B. Brożek, M. Soniewicka, W. Załuski, Paradoksy bioetyki prawniczej, Warszawa 2010, s. 82-112.

43 Jedną z najgłośniejszych była sprawa Baby M. z 1986 r. Matka surogatka, zarazem matka biologiczna dziecka urodzonego w oparciu o umowę o macierzyństwo zastępcze, ostatecznie nie chciała wydać go rodzicom zamawiającym. Sąd zastanawiał się, czy można zrównać status matki zastępczej (nie tylko biologicznej, ale też genetycznej) ze statusem dawcy nasienia. Uznanie takiej umowy za nieważną spowodowało wzrost cen za usługę na "czarnym rynku” (z 10 do 25 tys. dolarów wynagrodzenia dla matki zastępczej i aż do 75 tys. wszystkich kosztów - za pośrednictwo, opiekę lekarską itd.). Skutkowało to rozkwitem tzw. turystyki reprodukcyjnej, zwłaszcza do Indii, gdzie tego typu umowy są legalne, a cena usługi wydaje się atrakcyjna (wszystkie koszty, łącznie z podróżą, zamykają się w cenie 25 tys. dolarów).

44 M. Soniewicka, op. cit., s. 103-105.

45 Np. sprawa Jonshon v. Calvert, w której sąd uznał ostatecznie priorytet "matki zamawiającej”, zarazem „matki genetycznej”; M. Soniewicka, op. cit., s. 106-107. 
obrazuje, że rozpoczęło się $\mathrm{w}$ praktyce mieszanie genów pochodzących od kilku osób. Można to bez wątpienia uznać za poważną ingerencję w prawo natury. Pojawia się pytanie: jaki będzie status „kobiety dawczyni”. Będzie drugą mamą? Matką zastępczą? Matką drugiej kategorii (z racji mniejszego udziału w DNA dziecka)? ${ }^{47}$

Postęp biotechnologiczny $\mathrm{w}$ dziedzinie medycyny wiąże się $\mathrm{z}$ „przewartościowaniem" tradycyjnych paradygmatów moralności i prawa. Być może niebawem - wskutek rozwoju medycyny - pojęcia: „małżeństwo” i „rodzina” utracą w ogóle przypisywany im tradycyjnie prokreacyjny charakter. Może się tak stać m.in. za sprawą tzw. ektogenezy człowieka. Z perspektywy wiedzy medycznej oraz współczesnych technologii ciąża może się odbywać w ogóle bez udziału rodziców. W takim przypadku płód, powstały - dzięki in vitro - poza organizmem matki rozwijałby się w sztucznej macicy. Możliwości współczesnej medycyny wskazują więc, że być może niebawem rozpocznie się epoka bądź to definitywnie kończąca z macierzyństwem naturalnym, bądź dająca możliwość wyboru albo macierzyństwa naturalnego, albo sztucznego. Tym samym, z coraz większą niepewnością będzie się wiązać sposób definiowania pojęć: „małżeństwo" i „rodzina”.

\section{Podsumowanie}

Przemiany w sposobie myślenia skutkujące zdolnością do akceptowania różnorodnych światopoglądów oraz obyczajów to bardzo powolny proces. Widać wyraźnie, że pod wpływem wielokulturowości zauważalnej dziś - głównie dzięki mobilności ludzi i technologiom informacyjnym - zmienia się podejście do małżeństwa i rodziny. Wyraźna staje się potrzeba redefinicji tych pojęć. Nowe spojrzenie implikowane jest niewątpliwie kryzysem tradycyjnego małżeństwa i rodziny oraz upowszechnianiem się w świadomości społecznej wiedzy na temat tego, że związki małżeńskie i rodzinne są bardzo różnorodne (począwszy od monogamii „zamkniętej i „otwartej”, przez zróżnicowane związki poligamiczne: poligynię i poliandrię do małżeństw multilateralnych). Inne niż monogamia formy małżeństw praktykowane były przez różne kultury i w wielu krajach przetrwały do dziś. Od wieków istniały też mniej lub bardziej uznawane związki osób tej samej płci. Wraz z coraz bardziej permisywnym nastawieniem do seksualności widoczne jest „uwalnianie się” najbardziej prywatnych obszarów życia społecznego spod kontroli państwa i społeczeństwa. Instytucja małżeństwa traci stopniowo swój heteroseksualny charakter i zaczyna obejmować także partnerów homoseksualnych. Również postęp 
biotechnologiczny podważa fundamenty tradycyjnych definicji pojęć: „małżeństwo" i „rodzina" jako m.in. służących naturalnej prokreacji. Biorąc pod uwage powyższe uwarunkowania wydaje się, że legalizacja związków partnerskich w Polsce jest tylko kwestią czasu.

\section{Bibliografia}

Bauman Z., Płynna nowoczesność, Kraków 2006.

Bauman Z., Zindywidualizowane społeczeństwo, Gdańsk 2008.

Berger P. L., Zasada watpliwości. Poza relatywizmem i fundamentalizmem, „Dziennik” 2008, nr 93, dodatek „Europa”.

Bront J., Nowacka B., Różnorodność związków małżeńskich na świecie, Krynica Morska 2008.

Bunikowski D., Podstawowe kontrowersje dotyczace ingerencji prawa w sferę moralności, Toruń 2010.

Eksridge W., Equality Practice Civil Union and Future of Gay Rights, New York London 2003.

Fiedorczyk P., Attempts at Redefining the Family in Contemporary Polish Law, "International Journal of the Jurisprudence of the Family" 2012, nr 3.

Fukuyama F., Wielki wstrząs. Natura ludzka a budowa porządku społecznego, Warszawa 2000.

Giddens A., Socjologia, Warszawa 2012.

Jabłoński D., Ostasz L., Zarys wiedzy o rodzinie, małżeństwie, kohabitacji i konkubinacie: perspektywa antropologii kulturowej i ogólnej, Olsztyn 2011.

Klinowski M., Moralność, reprodukcja i homoseksualizm, „Diametros” 2005, nr 5.

Kossobudzka M., Dwie mamy i jeden tata?, "Gazeta Wyborcza” z 29 października 2012 r.

Lewandowska A., Nieprzeciętność a formy małżeństw i demokracja, [w:] Nieprzeciętność. Dylemat wolności, red. M. Szyszkowska, A. Rossmanith, Warszawa 2013.

Libiszowska-Żółtkowska M., Sekularyzacja - wróg czy sprzymierzeniec Kościoła katolickiego w Polsce, [w:] Sekularyzacja jako wyzwanie dla religii i Kościoła. Mity i rzeczywistość, red. J. Baniak, Poznań 2006.

Mariański J., Kontrowersje wokół relacji religii i moralności. Tożsamość czy rozbieżność? Studium socjologiczne, Torun 2014.

Mill J. S., Utylitaryzm. O wolności, Warszawa 2005.

Pilch P., Modele regulacji prawnych dotyczacych związków partnerskich obowiązujące w krajach europejskich - rys historyczny, www.files.gildia.pl/reklama/abiekt/ PPilch_ARTYKUL.pdf.

Pietrzykowski T., Wyzwania moralne. Etyczne problemy prawa, Katowice 2010. 
Rawls J., Teoria sprawiedliwości, Warszawa 1994.

Russell B., Władza i jednostka, Warszawa 1997.

Sadurski W., Neutralność moralna prawa. (Przyczynek do teorii prawa liberalnego), „Państwo i Prawo" 1990, z. 7.

Shell S., The Liberal Case Against Gay Marriage, „The Public Interest” 2004, nr 156.

Soniewicka M., Prokreacja medycznie wspomagana, [w:] J. Stelamch, B. Brożek, M. Soniewicka, W. Załuski, Paradoksy bioetyki prawniczej, Warszawa 2010.

Toffler A., Trzecia fala, Warszawa 1986.

Tokarczyk R., Wspótczesne kultury prawne, Warszawa 2012. 